\title{
TRPM3 Gene
}

National Cancer Institute

\section{Source}

National Cancer Institute. TRPM3 Gene. NCI Thesaurus. Code C124909.

This gene is involved in calcium homeostasis. 